Int. J. Morphol.,

32(1):279-293, 2014

\title{
Animal Models of Nutritional Induction of Type 2 Diabetes Mellitus
}

\author{
Modelos Animales de Inducción Nutricional para Diabetes Mellitus Tipo 2
}

\author{
Sandra Barbosa-da-Silva*; Isabele Bringhenti Sarmento*; Thereza C. Lonzetti Bargut*; \\ Vanessa Souza-Mello*; Marcia Barbosa Aguila* \& Carlos A. Mandarim-de-Lacerda*
}

\begin{abstract}
BARBOSA-DA-SILVA, S.; SARMENTO, I. B.; BARGUT, T. C. L.; SOUZA-MELLO, V.; AGUILA, M. B. \& MANDARIM-DELACERDA, C. A. Animal models of nutritional induction of type 2 diabetes mellitus. Int. J. Morphol., 32(1):279-293, 2014.

SUMMARY: Type 2 diabetes mellitus (DM2) is the most common chronic metabolic disease, affecting approximately $6 \%$ of the adult population in the Western world. This condition is a major cause of cardiovascular disease, blindness, renal failure, and amputations, with increasing prevalence worldwide. The influence of obesity on type 2 diabetes risk is determined by the degree of obesity and by body fat localization, with insulin resistance (IR) being the main link between these metabolic diseases. Experimental studies have shown that dietary factors, and particularly lipids, are strongly positively associated with body mass (BM) gain; IR; and, consequently, type 2 diabetes. Similarly, excessive consumption of energy-dense carbohydrate-rich foods can trigger the onset of type 2 diabetes. Additionally, maternal dietary inadequacies at conception and/or during the gestational period have been proposed to lead to developmental programming of excessive BM gain and metabolic disturbances in offspring, such as abnormal glucose homeostasis, reduced wholebody insulin sensitivity, impaired beta-cell insulin secretion and changes in the structure of the pancreas. Metabolic disruption is strongly associated with deleterious effects on beta-cell development and function. However, alterations in the amount and quality of dietary fat can modify glucose metabolism and insulin sensitivity. In this way, certain oils have gained attention in experimental research for their beneficial effects. Olive oil, a source of monounsaturated fatty acids (MUFAs), got attention in the past for its capacity to prevent cardiovascular diseases. Nevertheless, it is currently known that this oil also improves insulin sensitivity and glycemic control. Canola oil, flaxseed oil and especially fish oil (rich in n-3 polyunsaturated fatty acids) were first described as effective dietary nutrients against hypertriglyceridemia but now are known to have positive effects on glucose metabolism as well.
\end{abstract}

KEY WORDS: Animal models; Nutritional induction; Metabolic disease; Type 2 diabetes mellitus.

\section{INTRODUCTION}

Animal experimentation has a long history of contributions to the fields of diabetes and metabolic disease research. Currently, most experiments are performed in rodents. Several toxins, including streptozotocin and alloxan, induce type 1 diabetes mellitus (DM1). Selective inbreeding has produced strains of animals that are considered to be reasonable models of both DM1 and type 2 diabetes mellitus (DM2) and of related phenotypes, such as obesity and insulin resistance (IR). In recent years, new animal models for the study of diabetes, including knocking, generalized knockout and tissue-specific knockout mice and diet models, have been used to induce DM2 (Rees \& Alcolado, 2005).

The intake of a high fat (HF) diet is an independent risk factor for becoming overweight in mice. Therefore, an HF diet is a suitable model for studying DM2, mimicking the current epidemic of diet-induced obesity in humans.
Retrospective epidemiological studies first detected associations between the prenatal and perinatal environments and the development of metabolic syndrome in adulthood (Junien \& Nathanielsz, 2007). Insufficient (protein restriction or global energy restriction) and excessive (HF diet) maternal food supplies impair different pathways but have the same endpoint, leading to IR and DM2 in offspring in adult life (Barker, 2006).

Different types of fat in the diet can drive different responses in glucose homeostasis and insulin sensitivity (Tierney \& Roche, 2007). In this way, edible oils have emerged as possible improvers of glucose and insulin metabolism (Moon et al., 2010).

This review aimed to describe the animal models commonly used to study DM2, focusing on dietary models 
(especially diets rich in lipids, sucrose and fructose), maternal-fetal programming of pancreatic function and the action of edible oils in DM2.

\section{A. Mouse models.}

C57BL/6 mice are genetically susceptible to obesity (central adiposity accompanied by metabolic abnormalities), impaired glucose tolerance, and DM2 when fed an HF diet. Moreover, C57BL/6 mice are susceptible to the fatty acid (FA) composition of HF diets, resulting in the manifestation of altered disease phenotypes (Lin et al., 2000). The diabetes/obesity syndrome worsens with time and with increasing obesity. At 16 weeks, C57BL/6 mice fed an HF diet develop adipocyte hyperplasia and hypertrophy (Black et al., 1998).

In addition, another inbred mouse model, the NagoyaShibata-Yasuda (NSY) mouse, is suitable for the study of DM2 (Shibata \& Yasuda, 1980). The NSY mouse's diabetes closely mimics human DM2, i.e. is age dependent and characterized by impaired insulin secretion and action, mild obesity with visceral fat accumulation and polygenic inheritance. Moreover, environmental factors such as an HF diet and sucrose administration accelerate the development of the disease, indicating that the animal model is a model for human DM2 (Ikegami et al., 2004).

The mice B6.Cg-Lepo ${ }^{\mathrm{b} / \mathrm{J}}$ and B6.BKS (D)-Leprd ${ }^{\mathrm{b} / \mathrm{J}}$ have a phenotype of spontaneous DM2 development, with hyperphagia, obesity after four weeks of age and glucose intolerance with transient hyperglycemia, followed by hyperinsulinemia (Dubuc, 1976) and pancreatic islet betacell hypertrophy without atrophy (Dong et al., 2006).

NONcNZO10/LtJ mice develop DM2 by dietary induction, with moderate obesity and without hyperphagia, when fed a $27 \mathrm{kcal} \%$ fat diet. Males change from impaired glucose tolerance to stable non-fasting hyperglycemia by 10 weeks of age. Moderately elevated plasma insulin is observed, and islets transition from hypertrophy and hyperplasia to atrophy by 24 weeks (Leiter \& Reifsnyder, 2004). Table I summarizes animal models with spontaneous or diet-induced DM2.

\section{B. Dietary models}

HF diets. Regarding the multifaceted etiology of obesity, diet remains a key factor in inducing obesity. Obesogenic diets are high in energy content, often consisting of palatable foods that lead to obesity after extended exposure (Archer \& Mercer, 2007).

The deleterious effects of diets with saturated fat overload are well described in the literature. Studies have shown that the long-term administration of diets containing $40 \%$ to $60 \%$ of lipids promotes metabolic disorders; increases the production of inflammatory cytokines; induces IR, arterial hypertension and obesity in animal models and humans (Flanagan et al., 2008); and induces adipocyte hypertrophy (Barbosa-da-Silva et al., 2012), DM2, hypertriglyceridemia (Fraulob et al., 2010) and liver steatosis in mice (Aguila et al., 2003; Barbosa-da-Silva et al., 2013). The source of lipid in the diet is an important feature for the induction of obesity and diabetes (commonly saturated fat, or lard, is used). Table II summarizes certain diet compositions used in the literature.

Diet combinations vary in the literature, such as HF, high-sucrose; HF, low-sucrose; low fat, high-sucrose; and low fat, low-sucrose. Both the C57BL/6 and the $\mathrm{A} / \mathrm{J}$ strains respond to diet with an increase in their body mass (BM), but their BM tends to be smaller with excess sucrose consumption compared with an HF diet (Black et al.). Wistar rats are more responsive to a sucrose increase, whereas C57BL/6 mice are more responsive to an HF diet (Chen et al., 2011).

Sucrose diet. A high-sucrose diet is a common food diet in developed countries and is considered as an environmental

Table I. Mouse models to develop spontaneously or diet-induced type 2 diabetes. Adapted from: The Jackson Laboratory (http://www.jax.org/).

\begin{tabular}{|c|c|c|c|c|}
\hline Phenotypes & B6.BKS(D)-Leprd $d^{b} / \mathrm{J}$ & C57BL/6J & NONcNZO10/LtJ & $\mathrm{KK} . \mathrm{Cg}-A^{y} / \mathrm{J}$ \\
\hline Induced or spontaneous & Spontaneous & Diet-induced & Diet-induced & Spontaneous \\
\hline Genetics & Polygenic & Polygenic & Polygenic & Polygenic \\
\hline Onset & Young & Mature & Mature & Mature \\
\hline Sex & $\mathrm{M}, \mathrm{F}$ & $\mathrm{M}$ & M & $\mathrm{M}, \mathrm{F}$ \\
\hline Hyperinsulinemia & Severe & Mild & Moderate & Severe \\
\hline Glucose intolerance & Yes & Yes & Yes & Yes \\
\hline Hyperglycemia & Moderate (transient) & Mild/Moderate & Moderate/Severe & Yes \\
\hline Islet atrophy & No(hyperplasia only) & No & Variable & Hypertrophy \\
\hline Nephropathy & No & No & Yes (mild) & Yes \\
\hline
\end{tabular}


Table II. Types of diets used to induce type 2 diabetes in mouse models.

\begin{tabular}{lccccc}
\hline Nutrients (\%) & $\begin{array}{c}\text { Surwit } \text { et al. } \\
\text { (1988) }\end{array}$ & $\begin{array}{c}\text { Black } \text { et al. (1998) } \\
\text { (High-fat-low-sucrose) }\end{array}$ & $\begin{array}{c}\text { Winzell \& Ahren } \\
\mathbf{( 2 0 0 4 )}\end{array}$ & $\begin{array}{c}\text { Fraulob } \text { et al. } \\
\mathbf{( 2 0 1 0 )}\end{array}$ & $\begin{array}{c}\text { Oliveira } \text { et al. (2013) } \\
\text { (High-fat-high- sucrose) }\end{array}$ \\
\hline Carbohydrates & & & & & \\
$\quad$ a. Sucrose & $36.8 \%$ & ---- & --- & $8 \%$ & $32 \%$ \\
b. Starch & --- & $26 \%$ & $25.6 \%$ & $18 \%$ & $12 \%$ \\
Protein & $20.5 \%$ & $16 \%$ & $16 \%$ & $14 \%$ & $14 \%$ \\
Lipids & $35.8 \%$ & $58 \%$ & $58 \%$ & $60 \%(\operatorname{lard})$ & $42 \%$ (lard) \\
\hline
\end{tabular}

factor that leads to the development of obesity and DM2 (Walker et al., 2007), causing impaired insulin action through sucrose's effects on the liver (Storlien et al., 1988).

The ability of high sucrose intake to induce obesity and IR in rodents has yielded conflicting results (Santure $e t$ $a l ., 2002)$ because its effects depend not only on the species or animal strain but also on the way that the sucrose is provided. In Wistar rats fed a normal-fat chow diet, the addition of sucrose to the drinking water $(30 \%)$ as an extra caloric source has been shown to be a successful way of inducing abdominal obesity, hypertension, hyperlipidemia and hyperinsulinemia (Oliart Ros et al., 2001). However, whether sucrose-containing drinking water induces symptoms in other species is unclear. C57BL/6 mice are resistant to sucrose treatment; replacing starch with an equal amount of sucrose in fatty acids (MUFAs), attracted attention in the past for its capacity to prevent cardiovascular diseases.

Solid food with a normal fat content failed to induce obesity and hyperinsulinemia in C57BL/6J mice (Sumiyoshi et al., 2006). However, a recent study demonstrated that although a sucrose-rich diet (32\%) does not lead to obesity in C57BL/6 mice, the diet has the potential to cause changes in adipocytes (hypertrophy), as well as glucose intolerance, hyperinsulinemia, hyperlipidemia, hepatic steatosis and increased levels of inflammatory cytokines (Oliveira et al., 2014).

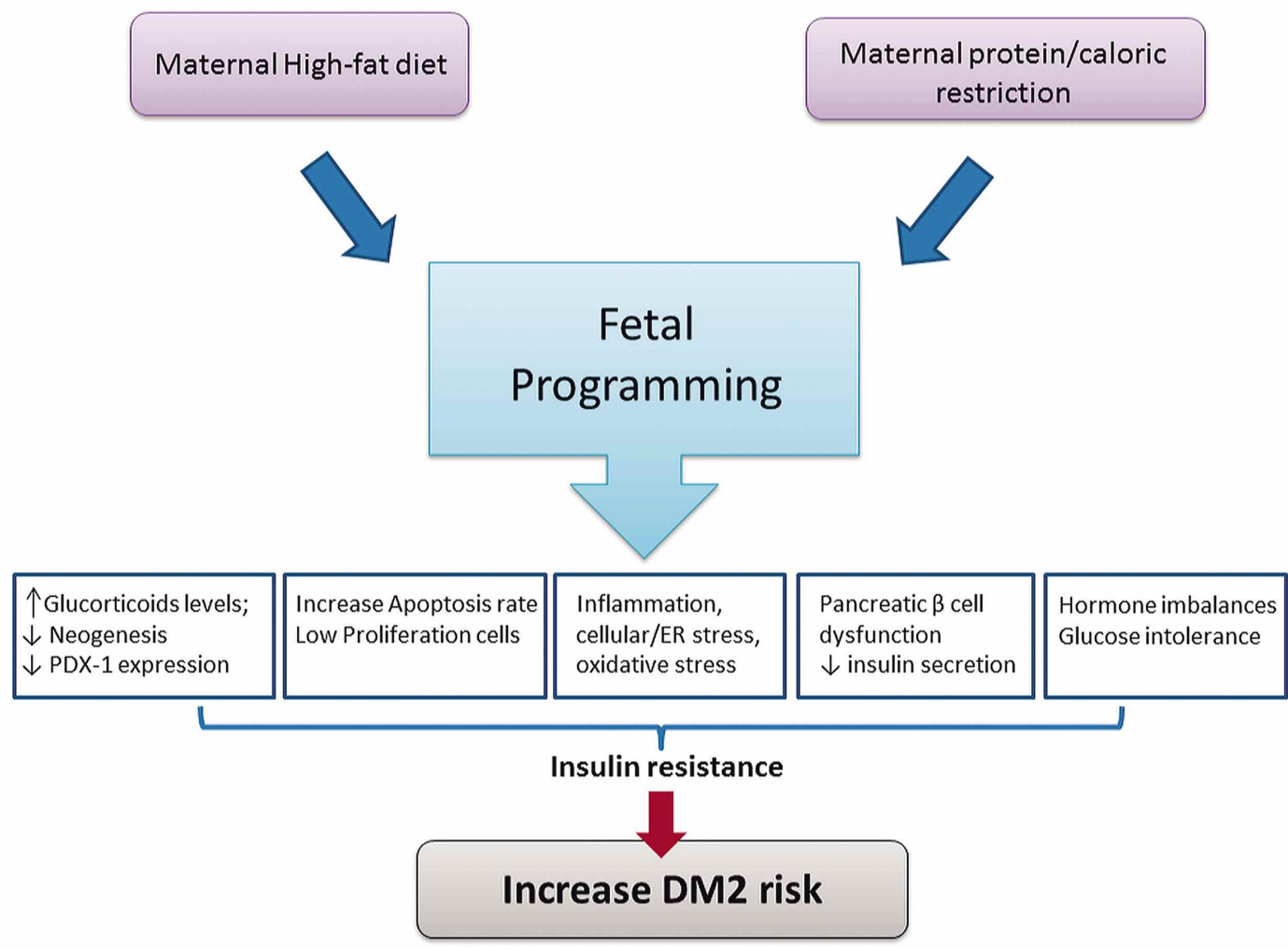

Fig. 1. Nutritional basis of fetal programming. PDX1= Pancreatic and duodenal homeobox 1; ER= endoplasmicreticulum; DM2= type 2 diabetes. 
In rodents, a high-sucrose diet induces IR independently of changes in body composition. The mechanism in rodents may involve alteration of post-receptor insulin signaling. Indeed, sucrose does not alter the amount of insulin receptors, insulin receptor substrate (IRS)1, IRS-2, or phosphatidylinositol 3-kinase (PI3K) in hepatocytes, and the phosphorylation of insulin receptors upon exposure to insulin is not altered. However, the phosphorylation of IRS-1 and IRS-2 is reduced, indicating that sucrose impairs post-receptor insulin signaling (Pagliassotti \& Prach, 1995). Unexpectedly, PI3K activity increases, suggesting a possible compensatory mechanism (Pagliassotti et al., 2002). In the skeletal muscle of rats, a high-sucrose diet (Eiffert et al., 1991) decreases insulininduced insulin receptor and IRS-1 phosphorylation.

Fructose diet. The introduction of high-fructose corn syrup led to a $30 \%$ increase in fructose consumption and a $100 \%$ increase in the consumption of free fructose (Bray et al., 2004), paralleling the rise in obesity from $13 \%$ to $34 \%$ since 1960 (Ford et al., 2011) and the subsequent rise in diagnosed DM2 from 5\% to 8\% since 1988 (Cowie et al., 2009). Fructose decreases insulin sensitivity in short-term clinical trials (Malik \& Hu, 2012) and is commonly used to induce IR in animal models (Ackerman et al., 2005). In animals, a high-fructose diet causes multiple symptoms of metabolic syndrome, such as IR, impaired glucose tolerance, hyperinsulinemia, hypertension and hypertriglyceridemia (Schultz et al., 2013).

Several mechanisms have been proposed to explain the increased BM gain associated with fructose intake. Fructose has been suggested to increase the palatability of food, with consequent overeating (Bray et al.). Acute fructose ingestion fails to stimulate both insulin and leptin secretion and attenuates postprandial ghrelin suppression (Teff et al., 2004); thus, prolonged consumption of high-fructose diets could lead to increased caloric intake and contribute to BM gain and obesity. Chronic fructose ingestion is associated with hyperleptinemia, which usually precedes obesity through leptin resistance, in rodents (Roglans et al., 2007) and humans (Le et al., 2006). However, BM seems not to be affected by high-fructose diet consumption (Schultz et al.).

\section{Maternal-fetal programming}

The term "fetal programming" or "imprinting" is used to describe a permanent phenomenon triggered by a body's response to injury or stimulation during a critical period of development (Lucas, 1991). This definition suggests that the fetus or neonate, when exposed to an atypical environment during a rapid growth phase, presents adaptive responses that may become permanent. The long-term effects are irre- parable and irreversible, being observed in adult life even in the absence of the stimulus that triggered the adaptive mechanism (Barker \& Clark, 1997).

Epidemiological studies have assessed the impact of malnutrition during pregnancy on the development of chronic disease in adulthood. Adults who were exposed to maternal malnutrition during pregnancy or after birth in Leningrad during World War II presented increased blood pressure, endothelial dysfunction and obesity and had a higher prevalence of cardiovascular diseases (Stanner et al., 1997) compared with control subjects born at the same time and not exposed to hunger. Similarly, evidence focusing on the "Dutch famine", which happened in the winter of 1944-45 after a food embargo imposed by Germany, has shown a higher incidence of obesity among adults who suffered from malnutrition in early intrauterine life (Roseboom et al., 2001).

Malnutrition induced by either protein restriction or caloric restriction during gestation and lactation in female rats resulted in the metabolic programming of several target organs in their offspring and was accompanied by adultonset diseases in those offspring (Almeida \& Mandarimde-Lacerda, 2005b, 2005a; Villar-Martini et al., 2009).

Maternal protein restriction and pancreatic function. Given the importance of amino acids, damage caused by protein deficiency encompasses changes in hormones and growth factors such as insulin and IGFs (a family of growth factors including insulin) that are required for normal fetal development and maturation, resulting in intrauterine growth retardation and neonatal microsomia (Barker). Indeed, published data have shown that protein deficiency during gestation yields increased blood pressure (Langley \& Jackson, 1994), glucose intolerance and IR (Ozanne \& Hales, 2002), with changes in the pancreatic architecture (Dahri et al., 1991).

Regarding pancreatic functional development, maternal protein restriction (diet with $8 \%$ protein) produces offspring with smaller islets, reduced vascularization and insulin content (Snoeck et al., 1990) and an increased apoptosis rate (Scaglia et al., 1997). Indeed, the endoplasmic reticulum (ER) stress-mediated apoptosis of beta cells and increased inflammatory mediator levels may contribute to and/or occur as a consequence of beta-cell dysfunction (Fonseca et al., 2011). The disruption of islet architecture is accompanied by an impaired secretory response to both glucose and amino acids, which is also observed in adulthood (Merezak et al., 2004). This metabolic alteration is associated with changes in the expression of key insulin signaling molecules, such as the p110beta subunit of PI3K, in adipose tissue (Ozanne et al., 2001). 
Another type of damage caused by protein restriction is mitochondrial dysfunction. Beta cells require a large input of energy (ATP) for normal performance, but their antioxidant defenses are deficient, causing higher production of reactive oxygen species (ROS) (Rashidi et al., 2009). The resulting oxidative stress leads to numerous defects in beta cells, such as reduced levels of insulin and a glucosemediated decrease in the proliferation and mass of beta cells, which are more prominent in males than in females (Theys et al., 2009).

Maternal caloric restriction and pancreatic function. Dams submitted to caloric restriction (to $40 \%$ to $50 \%$ of normal intake), especially in the last week of gestation, produce low-BM offspring. This alteration is followed by a reduction in the beta-cell mass and IR in adulthood (Bertin et al., 2002). Protein restriction provokes low proliferation of beta cells or an increased apoptosis rate, whereas caloric restriction affects islet neogenesis through a reduction in the embryonic beta-cell progenitor pool, leading to inappropriate postnatal beta-cell formation. Beta-cell development and maintenance are dependent on expression of the transcription factor PDX-1. An alteration in the expression of this transcription factor, including diminished expression, is a determinant of the emergence of IR because of the resulting structural changes in beta cells (Garofano et al., 1997).

Beta-cell formation is also affected by prenatal glucocorticoid exposure. Studies have shown that maternal caloric restriction increased both fetal and maternal corticosterone levels in rats (Blondeau et al., 2001). Fetal corticosterone concentrations are inversely correlated with fetal insulin secretion and postnatal beta-cell formation (Seckl, 2004). Glucocorticoid receptors are found in the pancreas during the embryonic development of rodents and humans, and glucocorticoids can bind to the $\mathrm{Pdx} 1$ promoter and thus suppress fetal endocrine cell differentiation (Bréant et al., 2006).

Maternal HF diet and pancreatic function. Given the increasing prevalence of obesity in pregnancy and its association with gestational diabetes, there is growing interest in evaluating the influence of maternal obesity on the development of chronic diseases in children (Oken et al., 2007). Inappropriate BM gain during pregnancy and maternal obesity affect offspring in the long term, such as by triggering precocious puberty and the development of an increased risk of obesity (Taylor \& Poston, 2007).

The emergence of maternal obesity during critical periods of development, involving both gestation (fetal environment) and lactation (postnatal environment), results inirreversible metabolic changes in adulthood for offspring, culminating in the development of obesity and glucose intolerance (Gregorio et al., 2013). In addition, experimental evidence demonstrates sexual dimorphism in mice due to maternal obesity (Ornellas et al., 2013).

HF diet administration to dams during critical periods of development exerts a direct effect on pancreatic beta-cell failure, resulting in the onset of IR and DM2 (Cerf et al., 2007). This issue is extremely relevant because data from the World Health Organization (WHO) estimate that in 2030, approximately 366 million people will have DM2 (Wild et al., 2004).

Chronic consumption of an HF diet during pregnancy and/or lactation can induce a process known as glucolipotoxicity. This process suggests that the simultaneous increase in glucose and blood lipids during pregnancy results in the intracellular accumulation of lipids that ultimately hurt the function and survival of fetal beta cells (Gniuli et al., 2008). When the environment is rich in lipids, the pancreatic beta cells become sensitive to these lipids and use them as fuel for energy, rather than glucose. Thus, the insulin release stimulated by glucose is impaired, and hyperglycemia results (Poitout \& Robertson, 2008).

Of note, isolated glucotoxicity induces permanent hyperglycemia in offspring, which contributes substantially to a reduction in the number of beta cells through apoptotic mechanisms (Donath et al., 1999). In contrast, lipotoxicity, characterized by chronic exposure to high blood lipid concentrations, impairs insulin secretion in the fetus and causes an increase in serum concentrations of glucose, with consequent of beta-cell loss and glucose homeostasis disruption (Skelly et al., 1998).

The severity of beta-cell failure relies on the progenitor's metabolic state during HF diet administration and on the duration of injury. The beta-cell mass is increased by beta-cell neogenesis (precursor cell differentiation) by proliferation or replication (from preexisting beta cells) and hypertrophy (increase in beta-cell size). In contrast, a reduction in the mass of beta cells is mainly associated with hypotrophy (reduced beta-cell size) and apoptosis (Ackermann \& Gannon, 2007). An imbalance in one of these beta-cell formation mechanisms or increased rates of apoptosis may result in a decrease in the beta-cell mass, leading to a decrease in the ability to secrete insulin (Leonardi et al., 2003). The literature indicates impairment of betacell development in newborns from mothers who received an HF diet during pregnancy (Cerf et al., 2005). These findings may be caused by beta-cell replication inhibition or increased apoptotic mechanisms (Cerf, 2010). 


\section{Insulin Resistance in Target Tissues.}

Insulin is an anabolic hormone released from beta cells after meals rich in carbohydrates and proteins. The two major roles of insulin in the body are (1) to promote glucose uptake in insulin-sensitive tissues (e.g., skeletal muscle and adipose tissue) and (2) to inhibit glucose production (i.e., glycogenolysis and gluconeogenesis) in organs such as the liver. These two mechanisms lead to glucose homeostasis, which also relies on insulin secretion by pancreatic beta cells (Ye, 2013).

The insulin response starts when insulin binds to its receptor, namely the insulin receptor, in cell membranes, which leads to receptor autophosphorylation. Consequently, IRS-1/2, which is a post-signaling intracellular protein, is phosphorylated at a tyrosine residue. These IRSs function as a docking site for the recruitment and activation of PI3K, which initiates a cascade of cellular responses that includes phosphorylation (activation) of protein kinase $\mathrm{B}$ (PKB), also known as Akt. When activated, Akt initiates several downstream pathways that regulate metabolism (Copps \& White, 2012). A summary of insulin signaling can be observed in Figure 2.

In skeletal muscle and adipose tissue, Akt activation results in glucose transporter type 4 (GLUT-4) translocation to the cell membrane. Lastly, GLUT-4 promotes the transport of glucose into the cytoplasm. These tissues are responsible for nearly all insulin-stimulated glucose uptake, with skeletal muscle responsible for approximately $90 \%$ of this activity. In the liver, instead of GLUT-4 translocation and glucose uptake, the activation of Akt leads to the formation of glycogen through the inactivation of glycogen synthase kinase 3 (Gsk $3 \alpha$, Gsk3 $\beta$ ). This event results in glycogen synthase activation and glycogen accumulation and

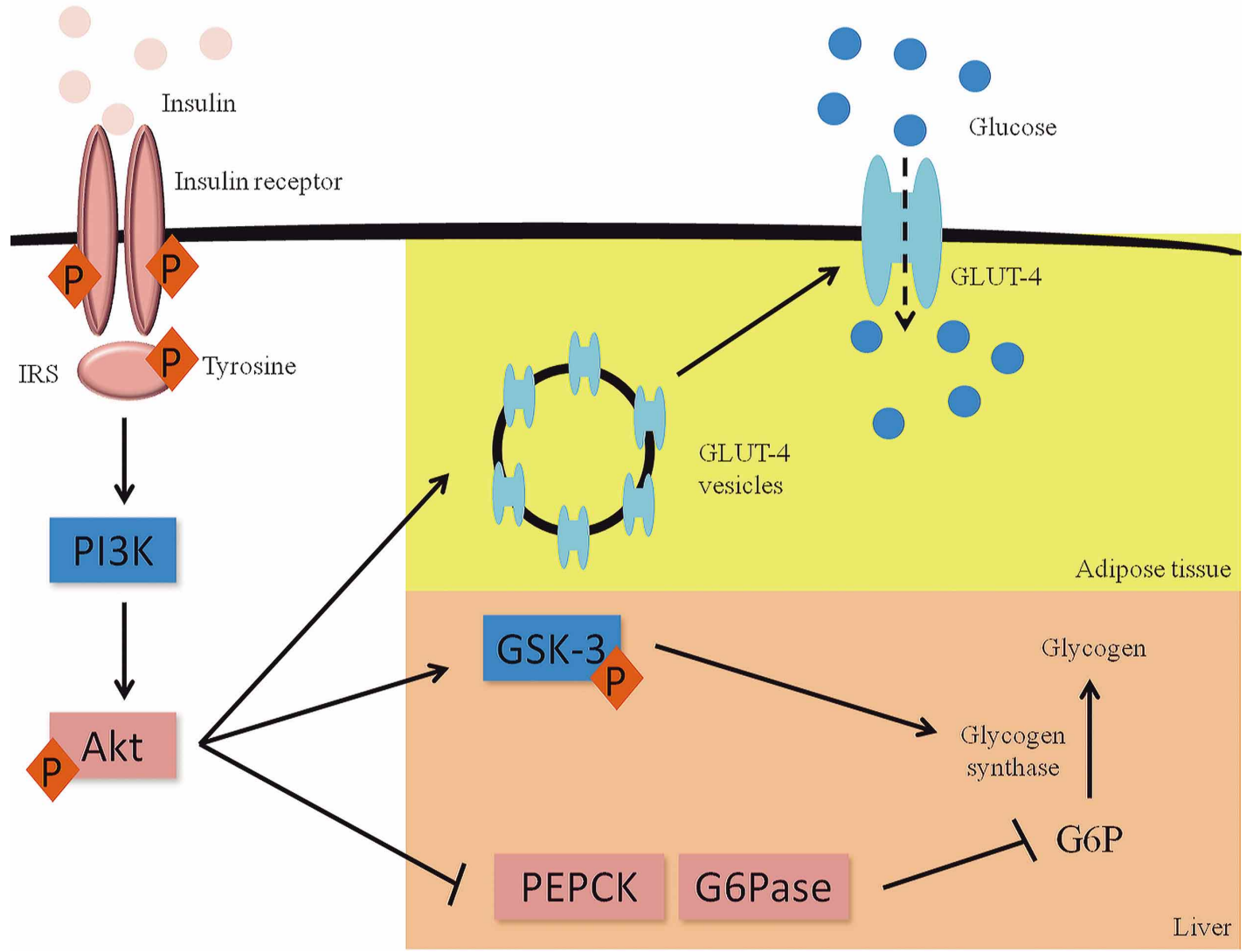

Fig. 2. Insulin signaling pathway. Insulin signaling starts when insulin binds to its receptor (insulin receptor). Consequently, IRS $1 / 2$ is phosphorylated in tyrosine, what leads to the downstream activation of PI3K and Akt. In white adipose tissue and skeletal muscle, Akt stimulates GLUT4 translocation to cell membranes thus allowing glucose to enter the cell. In liver, insulin stimulates glycogen production through phosphorylation of GSK-3 and consequently dephosphorylation of glycogen synthetase. Moreover, insulin inhibits gluconeogenesis by reducing enzymes of gluconeogenesis.

Full arrows represent stimulation, dotted arrows represent transport and interrupted lines represent inhibition. G6P=glucose-6phosphato; G6Pase= glucose-6-phosphatase; GLUT4= glucose transporter type 4; GSK-3= glycogen synthase kinase 3; IRS= insulin receptor substrate. 
inhibition of gluconeogenesis due to a decrease in the transcription of genes encoding gluconeogenic enzymes (Copps \& White; Lu et al., 2012).

Inflammation. Obesity is a state of low-grade inflammation, with elevated plasma concentration of cytokines and adipokines, such as tumor necrosis factor (TNF) $\alpha$, interleukin (IL)-6, plasminogen activator inhibitor (PAI)-1 and monocyte chemoattractant protein (MCP)-1 and a reduced plasma concentration of adiponectin (an antiinflammatory adipokine) (Catta-Preta et al., 2012; Ye).

One of the major pathways that are involved in inflammation and IR is IkB kinase- $\beta$ (IKK $\beta$ )/nuclear factor $\kappa \mathrm{B}(\mathrm{NF} \kappa \mathrm{b})$. Cytokines activate IKK $\beta$, which in turn leads to phosphorylation of $\mathrm{I} \kappa \mathrm{B} \alpha$. I $\mathrm{K} \mathrm{B} \alpha$ phosphorylation leads to protein ubiquitination and degradation, which releases NFkb to translocate into the nucleus and induce the gene expression of inflammatory mediators. IKK $\beta$ promotes serine phosphorylation of IRS-1, inhibiting insulin signaling, which causes IR. Moreover, cytokines activate the c-JUN N-terminal kinase (JNK)/AP-1 pathway. JNK, similar to IKK $\beta$, phosphorylates IRS-1 at a serine residue, impairing insulin signaling. JNK also activates AP1, a transcription factor related to the production of inflammatory mediators (Ye).

In the liver, inflammation begins due to chronic stimulation of lipid accumulation within hepatocytes (called steatosis). This event leads to the presence of inflammatory cytokines, together with macrophages (Kupffer cells). Although the mechanism has not been completely elucidated thus far, inflammation seems to induce gluconeogenesis as an attempt to protect the liver from steatosis by stimulating the conversion of FAs into glucose. Hepatic inflammation and related IR are linked to overexpression of IKK $\beta$ (Hijona et al., 2010).

Ectopic lipid accumulation (lipotoxicity). Fat and IR are associated, as FAs inhibit insulin-stimulated glucose uptake. Upon FA entrance into cells, the FAs are esterified by coenzyme A into acyl-CoAs, which are transferred to a glycerol backbone, forming monoacylglycerol (MAG), diacylglycerol (DAG) and triacylglycerol (TAG). The FAs can also esterify with sphingosine to form ceramides (Samuel \& Shulman, 2012). Skeletal muscle cells are protected from the deleterious effect of lipids by storing them as TAG, a mechanism that is very limited. Therefore, a great influx of lipids (as observed in obesity) promotes the formation of other molecules that function as intracellular signaling molecules, interfering with insulin signaling (e.g., DAG and ceramides). Lipotoxicity is the main cause of IR in skeletal muscle (Borén et al., 2013).
DAG results in the activation of members of the protein kinase $\mathrm{C}$ (PKC) family, namely, PKC $\theta$, which phosphorylates IRS-1/2 in serine residues, preventing the interaction between IRS-1/2 and the insulin receptor. Additionally, PKC $\theta$ is involved in the NFKB pathway, stimulating inflammation. Moreover, ceramide accumulation impairs the activation of Akt in a mechanism dependent on PKC $\theta$ (Amati, 2012).

Ectopic fat accumulation in the liver is called hepatic steatosis or non-alcoholic fatty liver disease (NAFLD), which is the most common chronic liver disease in the USA. This disease is the main cause of hepatic IR, and is generated by increased TAG input and reduced lipid output. Hepatic IR is related to DAG accumulation in hepatocytes, which leads to the activation of PKCE. This protein acts similarly to $\mathrm{PKC} \theta$, phosphorylating IRS-1/2 at serine residues and also impairing insulin receptor activity (Samuel \& Shulman).

ER stress. ER stress refers to a condition in which there is dysfunction in the ER due to excessive protein synthesis or the accumulation of unfolded or misfolded proteins in the ER lumen. ER stress lead to a cellular response called the unfolded protein response (UPR), which yields an increased protein folding capacity and a decreased unfolded protein load, thus restoring homeostasis. If this mechanism fails in its task, cells undergo apoptosis (Ozcan et al., 2004).

The UPR is closely related to inflammation and IR. Several proteins that are involved in UPR development also activate NFKB and JNK, leading to inflammation and impaired insulin signaling. Of note, inflammatory cytokines also exacerbate ER stress. In adipose tissue, ER stress participates in the dysregulation of adipokine secretion, with reduced secretion of adiponectin and elevated secretion of IL-6. Additionally, as mentioned before, ER stress induces inflammation through IKK activation (Flamment et al., 2012).

In the liver, ER stress leads to IR by different mechanisms. First, the UPR stimulates transcription factors that directly modify enzymes involved in gluconeogenesis and lipogenesis. Second, stress kinases involved in the UPR can directly interfere with insulin signaling through the activation of JNK and IKK (already discussed as inducers of IR). Lastly, the UPR induces hepatic fat accumulation (steatosis) due to the activation of sterol regulatory elementbinding protein (SREBP)-1c (a lipogenic transcription factor) in parallel with impaired very-low-density lipoprotein (VLDL) production, leading to IR, which also induces ER stress (Cnop et al., 2012). 


\section{E. Insulin resistance and edible oils.}

The amount and quality of dietary fat affect glucose homeostasis and insulin sensitivity because an excess of dietary saturated FAs (SFAs) is closely related to IR and DM2. Nevertheless, countless studies addressing the roles of other types of FAs, and especially unsaturated FAs, in IR and DM2 have been performed. In this section, we will discuss the effects of several edible oils, which were grouped according to their classifications, pertaining to the target tissues of IR (i.e., skeletal muscle, adipose tissue and liver) in experimental models.

Monounsaturated FAs (MUFAs). The main MUFA is oleic acid, which represents more than $90 \%$ of the MUFAs present in food and is mainly found in olive oil (Tierney \& Roche; Bulló et al., 2011). Olive oil gained prominence with the association of the "Mediterranean diet" with health benefits, including amelioration of IR and DM2 (Aguila \& Mandarimde-Lacerda, 2010).

It is well established that MUFAs normalize the FA composition of cell membranes, resulting in more fluidity, which is compromised in IR and DM2. SFAs are able to alter membranes' lipid structure and the binding of $G$ proteins and PKC to cellular membranes, thus interfering with cell signaling. MUFAs appear to normalize this condition, restoring regular cellular signaling (Perona et al., 2007).

Skeletal muscle also benefits from MUFA administration. Mice fed a high-olive-oil diet showed amelioration of glucose metabolism and insulin signaling (Rocca et al., 2001). In contrast to SFAs, MUFAs do not induce or protect against the intracellular accumulation of DAG, which is known to activate PKC $\theta$ (Obanda \& Cefalu, 2013). Due to diminished accumulation of DAG and therefore reduced stimulation of $\operatorname{PKC} \theta$, olive oil is able to preserve insulin signaling via maintenance of the IRS-1/PI3K pathway and GLUT-4 translocation (Moon et al.). Moreover, as MUFAs encourage normal levels of both DAG and PKC $\theta$, the inflammatory processes associated with $\mathrm{NFKB}$ remain unchanged and therefore do not interfere with IR (Coll et al., 2008). Olive oil downregulates IL-6 release, which is considered pro-inflammatory (Garcia-Escobar et al., 2010), suggesting that MUFAs interfere with the inflammatory process associated with IR. Nevertheless, the relationship between these effects and the DAG-PKC $\theta-\mathrm{NF} \kappa \mathrm{B}$ pathway remain to be clarified.

Additionally, olive oil was shown to be a potent stimulator of postprandial glucagon-like peptide (GLP)-1 secretion, which induces insulin secretion and inhibits glucagon release. Olive oil is able to stimulate the activation of $\mathrm{PKC} \zeta$, which is recognized as a mediator of GLP-1 secretion and which may be the link between olive oil and GLP-1 (Rocca et al.).

Polyunsaturated FAs (PUFAs). The two most consumed PUFAs in the diet are linoleic acid (an n-6 PUFA) and alphalinolenic acid (ALA; an n-3 PUFA), which account for more than $95 \%$ of the PUFAs consumed by the North American population. In the liver, these FAs are converted into longchain PUFAs (LC-PUFAs), which have higher numbers of carbon atoms and double bounds (Calder, 2011). As n-6 and n-3 PUFAs have distinct effects on IR, they will be discussed in separate sections.

n-6 PUFAs. Linoleic acid is present in many edible oils, and especially, soy, corn, sunflower and safflower oils (Calder). The effects of these n-6 PUFAs on IR and DM2 are still controversial.

Several studies have demonstrated beneficial or at least neutral effects of n-6 PUFAs. Rats fed an HF diet rich in safflower oil do not develop IR in their skeletal muscle due to augmentation of TAG levels and reduction of DAG levels (Lee et al., 2006). In contrast, rats injected with soybean oil or sunflower oil show IR associated with diminished GLUT-4 expression and translocation to the cell membrane of white adipose tissue (Poletto et al., 2010). A diet rich in safflower oil alters phosphorylation of the insulin receptor and IRS-1, diminishes the activity of PI3K and reduces protein expression of GLUT-4 in the skeletal muscle of mice (Taouis et al., 2002).

The most well described deleterious action of $n-6$ PUFAs is their pro-inflammatory activity. The arachidonic acid is incorporated into cell membranes generating inflammatory mediators called eicosanoids, which have high pro-inflammatory potential. Of course, this condition can be associated with IR development (Calder). For instance, the eicosanoid prostaglandin $\mathrm{E}^{2}$ is overproduced in pancreatic islets and contributes to the blunting of glucose-stimulated insulin secretion via a mechanism associated with reduced GLP-1 signaling (Kimple et al., 2013).

n-3 PUFAs. ALA is mainly found in flaxseed oil and canola oil. In the liver, ALA is converted, through a series of elongations, into an LC-PUFA, such as eicosapentaenoic acid (EPA) and docosahexaenoic acid (DHA). These two FAs are especially found in fish oil (Aguila \& Mandarim-deLacerda).

Evidence suggests that EPA and DHA appear to be the n-3 PUFAs with the most beneficial effects and that the body has a limited capacity to convert ALA into these LC- 
PUFAs because $\Delta 6$-desaturase, the converting enzyme, is rate limiting (Gregory et al., 2011). A study in diabetic rats found that both flaxseed and fish oils have comparable beneficial effects (Devarshi et al., 2013) and that mice fed a high-canola-oil diet did not present an elevation of inflammatory mediators or IR (Catta-Preta et al.). A study using mice deficient in $\Delta 6$-desaturase found that ALA has independent effects, although these effects are not of the same magnitude as the effects of fish oil, EPA or DHA (Monteiro et al., 2013). Therefore, we are now going to review studies on fish oil, EPA and DHA. A summary of the mechanisms can be found in Figure 3.

The intake of fish oil is able to alter the FA composition of cellular membranes. Higher intake of these n-3 PUFAs leads to increased cell membrane EPA and DHA levels and decreased levels of arachidonic acid (an n-6 PUFA), altering the $n-6 / n-3$ PUFA ratio. This change in the membrane lipid profile leads to altered fluidity that causes altered cellular signaling and also modifies the production of eicosanoids and other lipid mediators (reviewed elsewhere (Gonzalez-Periz et al., 2009)), which all contribute to the beneficial effects on IR (Calder).

In the liver, n-3 PUFAs appear to improve and/or prevent hepatic IR via suppressing lipogenesis and stimulating lipid catabolism, decreasing fat accumulation (Jelenik et al., 2010). In mice fed a fish oil diet, PPAR $\alpha$ (a transcription factor involved in mitochondrial beta- oxidation) is activated along with beta-oxidation enzymes, leading to preserved insulin sensitivity. Furthermore, this augmentation of beta-oxidation is accompanied by a reduction in intracellular DAG levels (Neschen et al., 2007). Beyond reduced PPAR $\alpha$ levels, n-3 PUFA-deficient mice present elevated expression and activity of SREBP-1c, the transcription factor responsible for hepatic lipogenesis, which leads to hepatic IR (Pachikian et al., 2011). In contrast, mice fed a fish oil diet show a reduction in levels of SREBP1c and its transcript, FA synthase (FAS) (Wakutsu et al., 2010).

In white adipose tissue, the effects of n-3 PUFAs on IR are dependent on the inflammatory process and especially the restoration of adiponectin production and secretion (Kalupahana et al., 2010). Mice fed a diet containing n-3 PUFAs exhibited elevated expression and production of adiponectin, which alleviated IR (Gonzalez-Periz et al.). Mice treated with EPA showed amelioration of IR due to diminished secretion of pro-inflammatory adipokines (e.g., MCP-1 and PAI-1) and elevated release of adiponectin (Kalupahana et al.). Moreover, the transcription factor NFKB mediates inflammation in obesity, which can be suppressed by n-3 PUFAs, leading to improvement of IR (Siriwardhana et al., 2012). The effects of n-3 PUFAs in WAT are also mediated by PPAR $\gamma$, whose activation enhances adiponectin production and promotes the apoptosis of large adipocytes, increasing the number of small adipocytes, which are more insulin sensitive (Magliano et al., 2013).

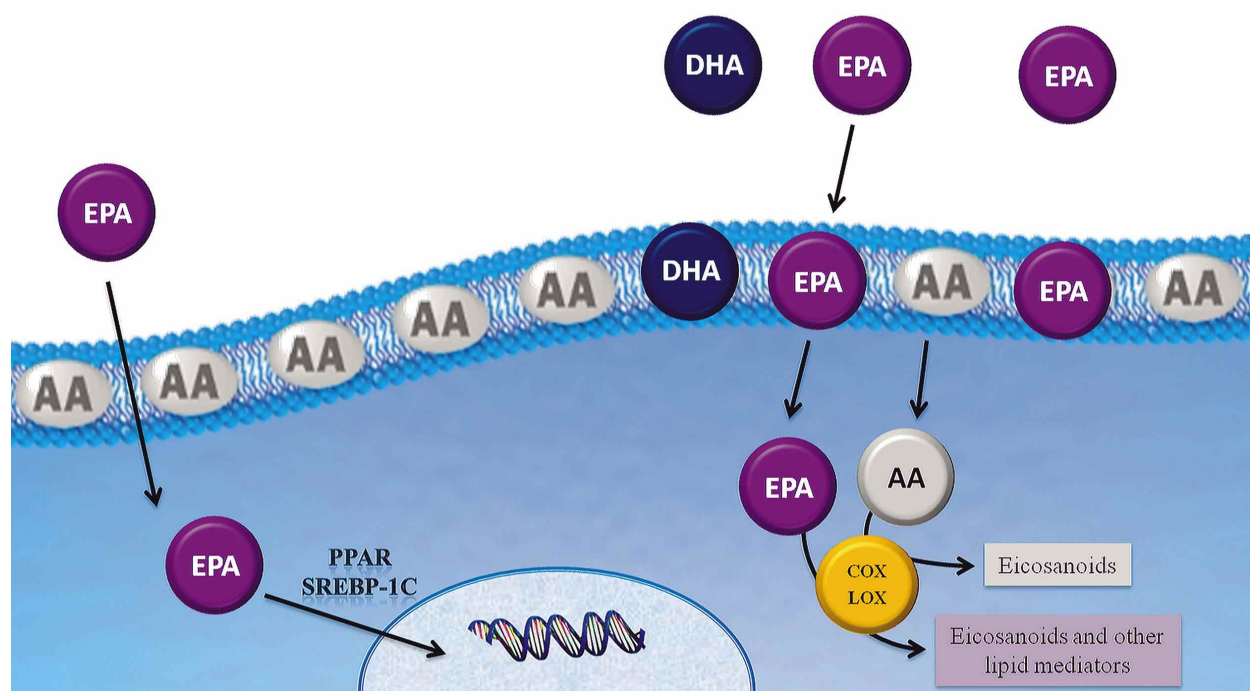

Fig. 3. Mechanisms of actions of EPA and DHA. EPA and DHA act through two main mechanisms. In the first one, they are converted by COX and LOX into inflammatory mediators, namely eicosanoids that have a less potent inflammatory activity and resolvins and protectins that are anti-inflammatory. In the second mechanism, they are transported through protein membranes, enter the cell and directly influence transcription factors.

$\mathrm{AA}=$ arachidonic acid $\mathrm{COX}=$ cicloxygenase; $\mathrm{DHA}=$ docosahexaenoic acid; $\mathrm{EPA}=$ eicosapentaenoic acid; $\mathrm{LOX}=$ lipoxygenase; $\mathrm{PPAR}=$ peroxisome proliferator-activated receptor; $\mathrm{SREBP}-1 \mathrm{c}=$ sterol regulatory element-binding protein-1c. 
Regarding skeletal muscle, rats fed a high-sucrose diet, in which a portion of lipids were substituted with fish oil, demonstrated diminished accumulation of DAG, together with reduced protein expression of $\mathrm{PKC} \theta$. These events were followed by the regularization of IRS-1 and GLUT-4 levels and, consequently, improvement of IR (D'Alessandro et al., 2013).

Final Remarks. Over the last century, obesity has become a major public health problem, and IR/DM2, an associated disease, has reached epidemic proportions. Experimental approaches are essential to mimic these metabolic disturbances to try to unravel the pathways involved and certain strategies to tackle or at least partly alleviate the resulting damage.

Dietary manipulations are the cornerstone of inducing DM2 in animals, as many of the cases of this disease are a direct result of inadequate nutrient intake coupled with sedentarism. An HF diet and even excessive intake of simple carbohydrates have emerged as the most recommended approaches. Additionally, the fetal origins of DM2 have drawn attention, representing a great economic burden because this phenotype can persist for generations.

Concerning therapy with edible oils, MUFAs (i.e., olive oil) and n-3 PUFAs (i.e., flaxseed, canola and fish oil) appear to be the most effective oils for preventing and/or treating IR. It is noteworthy that the prevention and treatment of IR can be achieved with a balanced diet (including all of these types of FFAs) and healthy habits (e.g., physical exercise) and that supplementation with these nutrients and oils should only be undertaken in special cases, with appropriate supervision. Moreover, the studies presented here were performed using mouse models, so the results may not be applicable to or observed in humans.

BARBOSA-DA-SILVA, S.; SARMENTO, I. B.; BARGUT, T. C. L.; SOUZA-MELLO, V.; AGUILA, M. B. \& MANDARIM-DELACERDA, C. Modelos animales de inducción nutricional para diabetes mellitus tipo 2. Int. J. Morphol., 32(1):279-293, 2014.

RESUMEN: La diabetes mellitus tipo 2 (DM2) es la enfermedad metabólica crónica más común, afectando aproximadamente al $6 \%$ de la población adulta en el mundo occidental. Esta condición es una causa importante de las enfermedades cardiovasculares, la ceguera, la insuficiencia renal, y las amputaciones, con un aumento de su prevalencia en todo el mundo. El riesgo de obesidad en la diabetes tipo 2 está determinado por el grado de obesidad y localización de la grasa corporal, siendo la resistencia a la insulina (RI) la principal relación entre estas enfermedades metabólicas. Los estudios experimentales han demostrado que los factores dietéticos, y en particular los lípidos, se asocian de manera importante con la masa corporal (MC), la IR y la diabetes tipo 2. Asimismo, el consumo excesivo de alimentos ricos en carbohidratos de alto contenido energético pueden provocar la diabetes tipo 2 . Además, se ha sugerido que una dieta materna inadecuada al momento de concebir o durante el período de gestación daría lugar al desarrollo de la excesiva MC y de trastornos metabólicos en los hijos, tales como la homeostasis anormal de la glucosa, reducción de la sensibilidad a la insulina en todo el cuerpo, el deterioro en la función de células beta, resistencia a la insulina y cambios en la estructura del páncreas. La alteración metabólica está asociada de forma importante con los efectos dañinos sobre el desarrollo y función de las células beta. Sin embargo, las alteraciones en la cantidad y la calidad de la grasa dietética pueden modificar el metabolismo de la glucosa como también la sensibilidad a la insulina. De esta manera, la investigación experimental ha enfocado la atención en algunos aceites debido a sus efectos beneficiosos. El aceite de oliva, es una fuente de monoinsaturados y actualmente se sabe que este aceite también mejora la sensibilidad a la insulina y el control glucémico El aceite de canola, el aceite de linaza y especialmente el aceite de pescado (rico en omega-3 los ácidos grasos poliinsaturados (PUFAs)) fueron descritos por primera vez como nutrientes de la dieta eficaces contra la hipertrigliceridemia, sin embargo, es sabido que además tienen efectos positivos sobre el metabolismo de la glucosa.

PALABRAS CLAVE: Modelos animales; Inducción nutricional; Enfermedad metabólica; Diabetes melitus tipo 2.

\section{REFERENCES}

Ackerman, Z.; Oron-Herman, M.; Grozovski, M.; Rosenthal, T.; Pappo, O.; Link, G. \& Sela, B.A. Fructose-induced fatty liver disease: hepatic effects of blood pressure and plasma triglyceride reduction. Hypertension, 45(5):1012-8, 2005.

Ackermann, A. M. \& Gannon, M. Molecular regulation of pancreatic beta-cell mass development, maintenance, and expansion. J. Mol. Endocrinol., 38(1-2):193-206, 2007.

Aguila, M. B. \& Mandarim-de-Lacerda, C. A. Beneficial effects of olive oil compared with fish, canola, palm and soybean oils on cardiovascular and renal adverse remodeling due to hypertension and diabetes in rat. In: Preedy, V. R. \& Watson, R. R. (Eds.). Olives and olive oil in health and disease prevention. Oxford, Academic Press, 2010. pp.787-94.

Aguila, M. B.; Pinheiro, A. R.; Parente, L. B. \& Mandarim-deLacerda, C. A. Dietary effect of different high-fat diet on rat liver stereology. Liver Int., 23(5):363-70, 2003. 
Almeida, J. R. \& Mandarim-de-Lacerda, C. A. Maternal gestational protein-calorie restriction decreases the number of glomeruli and causes glomerular hypertrophy in adult hypertensive rats. Am. J. Obstet. Gynecol., 192(3):945-51, 2005a.

Almeida, J. R. \& Mandarim-de-Lacerda, C. A. Overweight is gender-dependent in prenatal protein--calorie restricted adult rats acting on the blood pressure and the adverse cardiac remodeling. Life Sci., 77(12):1307-18, 2005b.

Amati, F. Revisiting the diacylglycerol-induced insulin resistance hypothesis. Obesity Rev., 13(Suppl. 2):40-50, 2012.

Archer, Z. A. \& Mercer, J. G. Brain responses to obesogenic diets and diet-induced obesity. Proc. Nutr. Soc., 66(1):124-30, 2007.

Barbosa-da-Silva, S.; da Silva, N. C.; Aguila, M. B. \& Mandarimde-Lacerda, C. A. Liver damage is not reversed during the lean period in diet-induced weight cycling in mice. Hepatol. Res., doi:10.1111/hepr.12138, 2013.

Barbosa-da-Silva, S.; Fraulob-Aquino, J. C.; Lopes, J. R.; Mandarim-de-Lacerda, C. A. \& Aguila, M. B. Weight cycling enhances adipose tissue inflammatory responses in male mice. PLoS One, 7(7):e39837, 2012.

Barker, D. J. Adult consequences of fetal growth restriction. Clin. Obstet. Gynecol., 49(2):270-83, 2006.

Barker, D. J. \& Clark, P. M. Fetal undernutrition and disease in later life. Rev. Reprod., 2(2):105-12, 1997.

Bertin, E.; Gangnerau, M. N.; Bellon, G.; Bailbe, D.; Arbelot De Vacqueur, A. \& Portha, B. Development of beta-cell mass in fetuses of rats deprived of protein and/or energy in last trimester of pregnancy. Am. J. Physiol. Regul. Integr. Comp. Physiol., 283(3):R623-30, 2002.

Black, B. L.; Croom, J.; Eisen, E. J.; Petro, A. E.; Edwards, C. L. $\&$ Surwit, R. S. Differential effects of fat and sucrose on body composition in $\mathrm{A} / \mathrm{J}$ and $\mathrm{C} 57 \mathrm{BL} / 6$ mice. Metabolism, 47(11):1354-9, 1998.

Blondeau, B.; Lesage, J.; Czernichow, P.; Dupouy, J. P. \& Bréant, B. Glucocorticoids impair fetal beta-cell development in rats. Am. J. Physiol. Endocrinol. Metab., 281(3):E592-9, 2001.

Borén, J.; Taskinen, M.R.; Olofsson, S. O. \& Levin, M. Ectopic lipid storage and insulin resistance: a harmful relationship. $J$. Intern. Med., 274(1):25-40, 2013.

Bray, G. A.; Nielsen, S. J. \& Popkin, B. M. Consumption of highfructose corn syrup in beverages may play a role in the epidemic of obesity. Am. J. Clin. Nutr., 79(4):537-43, 2004.

Bréant, B.; Gesina, E. \& Blondeau, B. Nutrition, glucocorticoids and pancreas development. Horm. Res., 65(Suppl. 3):98-104, 2006.
Bulló, M.; Lamuela-Raventós, R. \& Salas-Salvadó, J. Mediterranean diet and oxidation: nuts and olive oil as important sources of fat and antioxidants. Curr. Top. Med. Chem., 11(14):1797-810, 2011.

Calder, P. C. Fatty acids and inflammation: the cutting edge between food and pharma. Eur. J. Pharmacol., 668(Suppl. 1):S50-8, 2011.

Catta-Preta, M.; Martins, M. A.; Cunha Brunini, T. M.; MendesRibeiro, A. C.; Mandarim-de-Lacerda, C. A. \& Aguila, M. B. Modulation of cytokines, resistin, and distribution of adipose tissue in C57BL/6 mice by different high-fat diets. Nutrition, 28(2):212-9, 2012.

Cerf, M. E. High fat programming of beta-cell failure. Adv. Exp. Med. Biol., 654:77-89, 2010.

Cerf, M. E.; Williams, K.; Chapman, C. S. \& Louw, J. Compromised beta-cell development and beta-cell dysfunction in weanling offspring from dams maintained on a high-fat diet during gestation. Pancreas, 34(3):347-53, 2007.

Cerf, M. E.; Williams, K.; Nkomo, X. I.; Muller, C. J.; Du Toit, D. F.; Louw, J. \& Wolfe-Coote, S. A. Islet cell response in the neonatal rat after exposure to a high-fat diet during pregnancy. Am. J. Physiol. Regul. Integr. Comp. Physiol., 288(5):R11228, 2005.

Chen, G. C.; Huang, C. Y.; Chang, M. Y.; Chen, C. H.; Chen, S. W.; Huang, C. J. \& Chao, P. M. Two unhealthy dietary habits featuring a high fat content and a sucrose-containing beverage intake, alone or in combination, on inducing metabolic syndrome in Wistar rats and C57BL/6J mice. Metabolism, 60(2):155-64, 2011.

Cnop, M.; Foufelle, F. \& Velloso, L. A. Endoplasmic reticulum stress, obesity and diabetes. Trends Mol. Med., 18(1):59-68, 2012.

Coll, T.; Eyre, E.; Rodriguez-Calvo, R.; Palomer, X.; Sánchez, R. M.; Merlos, M.; Laguna, J. C. \& Vázquez-Carrera, M. Oleate reverses palmitate-induced insulin resistance and inflammation in skeletal muscle cells. J. Biol. Chem., 283(17):11107-16, 2008 .

Copps, K. D. \& White, M. F. Regulation of insulin sensitivity by serine/threonine phosphorylation of insulin receptor substrate proteins IRS1 and IRS2. Diabetologia, 55(10):2565-82, 2012.

Cowie, C. C.; Rust, K. F.; Ford, E. S.; Eberhardt, M. S.; ByrdHolt, D. D.; Li, C.; Williams, D. E.; Gregg, E. W.; Bainbridge, K. E.; Saydah, S. H. \& Geiss, L. S. Full accounting of diabetes and pre-diabetes in the U.S. population in 1988-1994 and 20052006. Diabetes Care, 32(2):287-94, 2009.

D'Alessandro, M. E.; Chicco, A. \& Lombardo, Y. B. Fish oil reverses the altered glucose transporter, phosphorylation, insulin recep- 
tor substrate-1 protein level and lipid contents in the skeletal muscle of sucrose-rich diet fed rats. Prostaglandins Leukot. Essent. Fatty Acids, 88(2):171-7, 2013.

Dahri, S.; Snoeck, A.; Reusens-Billen, B.; Remacle, C. \& Hoet, J. J. Islet function in offspring of mothers on low-protein diet during gestation. Diabetes, 40(Suppl. 2):115-20, 1991.

Devarshi, P. P.; Jangale, N. M.; Ghule, A. E.; Bodhankar, S. L. \& Harsulkar, A. M. Beneficial effects of flaxseed oil and fish oil diet are through modulation of different hepatic genes involved in lipid metabolism in streptozotocin-nicotinamide induced diabetic rats. Genes Nutr., 8(3):329-42, 2013.

Donath, M. Y.; Gross, D. J.; Cerasi, E. \& Kaiser, N. Hyperglycemiainduced beta-cell apoptosis in pancreatic islets of Psammomys obesus during development of diabetes. Diabetes, 48(4):73844, 1999.

Dong, F.; Zhang, X.; Yang, X.; Esberg, L. B.; Yang, H.; Zhang, Z.; Culver, B. \& Ren, J. Impaired cardiac contractile function in ventricular myocytes from leptin-deficient ob/ob obese mice. J. Endocrinol., 188(1):25-36, 2006.

Dubuc, P. U. The development of obesity, hyperinsulinemia, and hyperglycemia in ob/ob mice. Metabolism, 25(12):1567-74, 1976.

Eiffert, K. C.; McDonald, R. B. \& Stern, J. S. High sucrose diet and exercise: effects on insulin-receptor function of 12- and 24-mo-old Sprague-Dawley rats. J. Nutr., 121(7):1081-9, 1991.

Flamment, M.; Hajduch, E.; Ferre, P. \& Foufelle, F. New insights into ER stress-induced insulin resistance. Trends Endocrinol. Metab., 23(8):381-90, 2012.

Flanagan, A. M.; Brown, J. L.; Santiago, C. A.; Aad, P. Y.; Spicer, L. J. \& Spicer, M. T. High-fat diets promote insulin resistance through cytokine gene expression in growing female rats. $J$. Nutr. Biochem., 19(8):505-13, 2008.

Fonseca, S. G.; Gromada, J. \& Urano, F. Endoplasmic reticulum stress and pancreatic beta-cell death. Trends Endocrinol. Metab., 22(7):266-74, 2011.

Ford, E. S.; Li, C.; Zhao, G. \& Tsai, J. Trends in obesity and abdominal obesity among adults in the United States from 19992008. Int. J. Obes. (Lond.), 35(5):736-43, 2011.

Fraulob, J. C.; Ogg-Diamantino, R.; Fernandes-Santos, C.; Aguila, M. B. \& Mandarim-de-Lacerda, C. A. A Mouse Model of Metabolic Syndrome: Insulin Resistance, Fatty Liver and NonAlcoholic Fatty Pancreas Disease (NAFPD) in C57BL/6 Mice Fed a High Fat Diet. J. Clin. Biochem. Nutr., 46(3):212-23, 2010.

Garcia-Escobar, E.; Rodriguez-Pacheco, F.; Garcia-Serrano, S.; Gomez-Zumaquero, J. M.; Haro-Mora, J. J.; Soriguer, F. \&
Rojo-Martinez, G. Nutritional regulation of interleukin-6 release from adipocytes. Int. J. Obes. (Lond.), 34(8):1328-32, 2010.

Garofano, A.; Czernichow, P. \& Breant, B. In utero undernutrition impairs rat beta-cell development. Diabetologia, 40(10):12314, 1997.

Gniuli, D.; Calcagno, A.; Caristo, M. E.; Mancuso, A.; Macchi, V.; Mingrone, G. \& Vettor, R. Effects of high-fat diet exposure during fetal life on type 2 diabetes development in the progeny. J. Lipid. Res., 49(9):1936-45, 2008.

Gonzalez-Periz, A.; Horrillo, R.; Ferre, N.; Gronert, K.; Dong, B.; Moran-Salvador, E.; Titos, E.; Martinez-Clemente, M.; LopezParra, M.; Arroyo, V. \& Claria, J. Obesity-induced insulin resistance and hepatic steatosis are alleviated by omega- 3 fatty acids: a role for resolvins and protectins. FASEB J., 23(6):194657, 2009.

Gregorio, B. M.; Souza-Mello, V.; Mandarim-de-Lacerda, C. A. \& Aguila, M. B. Maternal high-fat diet is associated with altered pancreatic remodelling in mice offspring. Eur. J. Nutr., 52(2):759-69, 2013.

Gregory, M. K.; Gibson, R. A.; Cook-Johnson, R. J.; Cleland, L. G. \& James, M. J. Elongase reactions as control points in longchain polyunsaturated fatty acid synthesis. PLoS One, 6(12):e29662, 2011

Hijona, E.; Hijona, L.; Arenas, J. I. \& Bujanda, L. Inflammatory mediators of hepatic steatosis. Mediators Inflamm., 2010:837419, 2010.

Ikegami, H.; Fujisawa, T. \& Ogihara, T. Mouse models of type 1 and type 2 diabetes derived from the same closed colony: genetic susceptibility shared between two types of diabetes. ILAR J., 45(3):268-77, 2004.

Jelenik, T.; Rossmeisl, M.; Kuda, O.; Jilkova, Z. M.; Medrikova, D.; Kus, V.; Hensler, M.; Janovska, P.; Miksik, I.; Baranowski, M.; Gorski, J.; Hebrard, S.; Jensen, T. E.; Flachs, P.; Hawley, S.; Viollet, B. \& Kopecky, J. AMP-activated protein kinase alpha2 subunit is required for the preservation of hepatic insulin sensitivity by n-3 polyunsaturated fatty acids. Diabetes, 59(11):2737-46, 2010.

Junien, C. \& Nathanielsz, P. Report on the IASO Stock Conference 2006: early and lifelong environmental epigenomic programming of metabolic syndrome, obesity and type II diabetes. Obes. Rev., 8(6):487-502, 2007.

Kalupahana, N. S.; Claycombe, K.; Newman, S. J.; Stewart, T.; Siriwardhana, N.; Matthan, N.; Lichtenstein, A. H. \& MoustaidMoussa, N. Eicosapentaenoic acid prevents and reverses insulin resistance in high-fat diet-induced obese mice via modulation of adipose tissue inflammation. J. Nutr., 140(11):1915-22, 2010 . 
Kimple, M. E.; Keller, M. P.; Rabaglia, M. R.; Pasker, R. L.; Neuman, J. C.; Truchan, N. A.; Brar, H. K. \& Attie, A. D. Prostaglandin E2 receptor, EP3, is induced in diabetic islets and negatively regulates glucose- and hormone-stimulated insulin secretion. Diabetes, 62(6):1904-12, 2013.

Langley, S. C. \& Jackson, A. A. Increased systolic blood pressure in adult rats induced by fetal exposure to maternal low protein diets. Clin. Sci. (Lond.), 86(2):217-22, 1994.

Le, K. A.; Faeh, D.; Stettler, R.; Ith, M.; Kreis, R.; Vermathen, P.; Boesch, C.; Ravussin, E. \& Tappy, L. A 4-wk high-fructose diet alters lipid metabolism without affecting insulin sensitivity or ectopic lipids in healthy humans. Am. J. Clin. Nutr., 84(6):1374-9, 2006.

Lee, J. S.; Pinnamaneni, S. K.; Eo, S. J.; Cho, I. H.; Pyo, J. H.; Kim, C. K.; Sinclair, A. J.; Febbraio, M. A. \& Watt, M. J. Saturated, but not n-6 polyunsaturated, fatty acids induce insulin resistance: role of intramuscular accumulation of lipid metabolites. J. Appl. Physiol., 100(5):1467-74, 2006.

Leiter, E. H. \& Reifsnyder, P. C. Differential levels of diabetogenic stress in two new mouse models of obesity and type 2 diabetes. Diabetes, 53(Suppl. 1):S4-11, 2004.

Leonardi, O.; Mints, G. \& Hussain, M. A. Beta-cell apoptosis in the pathogenesis of human type 2 diabetes mellitus. Eur. J. Endocrinol., 149(2):99-102, 2003.

Lin, S.; Thomas, T. C.; Storlien, L. H. \& Huang, X. F. Development of high fat diet-induced obesity and leptin resistance in C57B1/ 6J mice. Int. J. Obes. Relat. Metab. Disord., 24(5):639-46, 2000 .

Lu, M.; Wan, M.; Leavens, K. F.; Chu, Q.; Monks, B. R.; Fernandez, S.; Ahima, R. S.; Ueki, K.; Kahn, C. R. \& Birnbaum, M. J. Insulin regulates liver metabolism in vivo in the absence of hepatic Akt and Foxo1. Nat. Med., 18(3):388-95, 2012.

Lucas, A. Programming by early nutrition in man. Ciba Found. Symp., 156: 38-55, 1991.

Magliano, D. C.; Bargut, T. C.; de Carvalho, S. N.; Aguila, M. B.; Mandarim-de-Lacerda, C. A. \& Souza-Mello, V. Peroxisome proliferator-activated receptors-alpha and gamma are targets to treat offspring from maternal diet-induced obesity in mice. PLoS One, 8(5):e64258, 2013.

Malik, V. S. \& Hu, F. B. Sweeteners and Risk of Obesity and Type 2 Diabetes: The Role of Sugar-Sweetened Beverages. Curr. Diab. Rep., doi:10.1007/s11892-012-0259-6, 2012.

Merezak, S.; Reusens, B.; Renard, A.; Goosse, K.; Kalbe, L.; Ahn, M. T.; Tamarit-Rodriguez, J. \& Remacle, C. Effect of maternal low-protein diet and taurine on the vulnerability of adult Wistar rat islets to cytokines. Diabetologia, 47(4):669-75, 2004.
Monteiro, J.; Askarian, F.; Nakamura, M. T.; Moghadasian, M. H. \& Ma, D. W. Oils rich in alpha-linolenic acid independently protect against characteristics of fatty liver disease in the Delta6-desaturase null mouse. Can. J. Physiol. Pharmacol., 91(6):469-79, 2013

Moon, J. H.; Lee, J. Y.; Kang, S. B.; Park, J. S.; Lee, B. W.; Kang, E. S.; Ahn, C. W.; Lee, H. C. \& Cha, B. S. Dietary monounsaturated fatty acids but not saturated fatty acids preserve the insulin signaling pathway via IRS-1/PI3K in rat skeletal muscle. Lipids, 45(12):1109-16, 2010.

Neschen, S.; Morino, K.; Dong, J.; Wang-Fischer, Y.; Cline, G. W.; Romanelli, A. J.; Rossbacher, J. C.; Moore, I. K.; Regittnig, W.; Munoz, D. S.; Kim, J. H. \& Shulman, G. I. n-3 Fatty acids preserve insulin sensitivity in vivo in a peroxisome proliferatoractivated receptor-alpha-dependent manner. Diabetes, 56(4):1034-41, 2007.

Obanda, D. N. \& Cefalu, W. T. Modulation of cellular insulin signaling and PTP1B effects by lipid metabolites in skeletal muscle cells. J. Nutr. Biochem., 24(8):1529-37, 2013.

Oken, E.; Taveras, E. M.; Kleinman, K. P.; Rich-Edwards, J. W. \& Gillman, M. W. Gestational weight gain and child adiposity at age 3 years. Am. J. Obstet. Gynecol., 196(4):322.e1-8, 2007.

Oliart Ros, R. M.; Torres-Marquez, M. E.; Badillo, A. \& Angulo Guerrero, O. Dietary fatty acids effects on sucrose-induced cardiovascular syndrome in rats. J. Nutr. Biochem., 12(4):20712,2001

Oliveira, L.; Santos, D.; Barbosa-da-Silva, S.; Mandarim-deLacerda, C. \& Aguila, M. The inflammatory profile and liver damage of a sucrose-rich diet in mice. J. Nut. Biochem., 25(2):193-200, 2014

Ornellas, F.; Mello, V. S.; Mandarim-de-Lacerda, C. A. \& Aguila, M. B. Sexual dimorphism in fat distribution and metabolic profile in mice offspring from diet-induced obese mothers. Life Sci., 93(12-14):454-63, 2013.

Ozanne, S. E.; Dorling, M. W.; Wang, C. L. \& Nave, B. T. Impaired PI 3-kinase activation in adipocytes from early growthrestricted male rats. Am. J. Physiol. Endocrinol. Metab., 280(3):E534-9, 2001

Ozanne, S. E. \& Hales, C. N. Early programming of glucose-insulin metabolism. Trends Endocrinol. Metab., 13(9):368-73, 2002.

Ozcan, U.; Cao, Q.; Yilmaz, E.; Lee, A. H.; Iwakoshi, N. N.; Ozdelen, E.; Tuncman, G.; Gorgun, C.; Glimcher, L. H. \& Hotamisligil, G. S. Endoplasmic reticulum stress links obesity, insulin action, and type 2 diabetes. Science, 306(5695):45761,2004

Pachikian, B. D.; Essaghir, A.; Demoulin, J. B.; Neyrinck, A. M.; Catry, E.; De Backer, F. C.; Dejeans, N.; Dewulf, E. M.; Sohet, 
F. M.; Portois, L.; Deldicque, L.; Molendi-Coste, O.; Leclercq, I. A.; Francaux, M.; Carpentier, Y. A.; Foufelle, F.; Muccioli, G. G.; Cani, P. D. \& Delzenne, N. M. Hepatic n-3 polyunsaturated fatty acid depletion promotes steatosis and insulin resistance in mice: genomic analysis of cellular targets. PLoS One, 6(8):e23365, 2011.

Pagliassotti, M. J.; Kang, J.; Thresher, J. S.; Sung, C. K. \& Bizeau, M. E. Elevated basal PI 3-kinase activity and reduced insulin signaling in sucrose-induced hepatic insulin resistance. Am. J. Physiol. Endocrinol. Metab., 282(1):E170-6, 2002.

Pagliassotti, M. J. \& Prach, P. A. Quantity of sucrose alters the tissue pattern and time course of insulin resistance in young rats. Am. J. Physiol., 269(3 Pt. 2):R641-6, 1995.

Perona, J. S.; Vögler, O.; Sánchez-Domínguez, J. M.; Montero, E.; Escribá, P. V. \& Ruiz-Gutierrez, V. Consumption of virgin olive oil influences membrane lipid composition and regulates intracellular signaling in elderly adults with type 2 diabetes mellitus. J. Gerontol. A Biol. Sci. Med. Sci., 62(3):256-63, 2007.

Poitout, V. \& Robertson, R. P. Glucolipotoxicity: fuel excess and beta-cell dysfunction. Endocr. Rev., 29(3):351-66, 2008.

Poletto, A. C.; Anhe, G. F.; Eichler, P.; Takahashi, H. K.; Furuya, D. T.; Okamoto, M. M.; Curi, R. \& Machado, U. F. Soybean and sunflower oil-induced insulin resistance correlates with impaired GLUT4 protein expression and translocation specifically in white adipose tissue. Cell Biochem. Funct., 28(2):114-21, 2010.

Rashidi, A.; Kirkwood, T. B. \& Shanley, D. P. Metabolic evolution suggests an explanation for the weakness of antioxidant defences in beta-cells. Mech. Ageing Dev., 130(4):216-21, 2009.

Rees, D. A. \& Alcolado, J. C. Animal models of diabetes mellitus. Diabet. Med., 22(4):359-70, 2005.

Rocca, A. S.; LaGreca, J.; Kalitsky, J. \& Brubaker, P. L. Monounsaturated fatty acid diets improve glycemic tolerance through increased secretion of glucagon-like peptide- 1 . Endocrinology, 142(3):1148-55, 2001.

Roglans, N.; Vila, L.; Farre, M.; Alegret, M.; Sanchez, R. M.; Vazquez-Carrera, M. \& Laguna, J. C. Impairment of hepatic Stat-3 activation and reduction of PPARalpha activity in fructose-fed rats. Hepatology, 45(3):778-88, 2007.

Roseboom, T. J.; van der Meulen, J. H.; Osmond, C.; Barker, D. J.; Ravelli, A. C. \& Bleker, O. P. Adult survival after prenatal exposure to the Dutch famine 1944--45. Paediatr. Perinat. Epidemiol., 15(3):220-5, 2001.

Samuel, V. T. \& Shulman, G. I. Mechanisms for insulin resistance: common threads and missing links. Cell, 148(5):852-71, 2012.
Santure, M.; Pitre, M.; Marette, A.; Deshaies, Y.; Lemieux, C.; Lariviere, R.; Nadeau, A. \& Bachelard, H. Induction of insulin resistance by high-sucrose feeding does not raise mean arterial blood pressure but impairs haemodynamic responses to insulin in rats. Br. J. Pharmacol., 137(2):185-96, 2002.

Scaglia, L.; Cahill, C. J.; Finegood, D. T. \& Bonner-Weir, S. Apoptosis participates in the remodeling of the endocrine pancreas in the neonatal rat. Endocrinology,138(4):1736-41, 1997.

Schultz, A.; Neil, D.; Aguila, M. B. \& Mandarim-de-Lacerda, C. A. Hepatic adverse effects of fructose consumption independent of overweight/obesity. Int. J. Mol. Sci., 14(11):21873-86, 2013.

Seckl, J. R. Prenatal glucocorticoids and long-term programming. Eur. J. Endocrinol., 151(Suppl. 3):U49-62, 2004.

Shibata, M. \& Yasuda, B. New experimental congenital diabetic mice (N.S.Y. mice). Tohoku J. Exp. Med., 130(2):139-42, 1980.

Siriwardhana, N.; Kalupahana, N. S. \& Moustaid-Moussa, N. Health benefits of n-3 polyunsaturated fatty acids: eicosapentaenoic acid and docosahexaenoic acid. Adv. Food Nutr. Res., 65:211-22, 2012.

Skelly, R. H.; Bollheimer, L. C.; Wicksteed, B. L.; Corkey, B. E. \& Rhodes, C. J. A distinct difference in the metabolic stimulusresponse coupling pathways for regulating proinsulin biosynthesis and insulin secretion that lies at the level of a requirement for fatty acyl moieties. Biochem. J., 331(Pt. 2):553-61, 1998.

Snoeck, A.; Remacle, C.; Reusens, B. \& Hoet, J. J. Effect of a low protein diet during pregnancy on the fetal rat endocrine pancreas. Biol. Neonate, 57(2):107-18, 1990.

Stanner, S. A.; Bulmer, K.; Andres, C.; Lantseva, O. E.; Borodina, V.; Poteen, V. V. \& Yudkin, J. S. Does malnutrition in utero determine diabetes and coronary heart disease in adulthood? Results from the Leningrad siege study, a cross sectional study. B. M. J., 315(7119):1342-8, 1997.

Storlien, L. H.; Kraegen, E. W.; Jenkins, A. B. \& Chisholm, D. J. Effects of sucrose vs starch diets on in vivo insulin action, thermogenesis, and obesity in rats. Am. J. Clin. Nutr., 47(3):420-7, 1988.

Sumiyoshi, M.; Sakanaka, M. \& Kimura, Y. Chronic intake of highfat and high-sucrose diets differentially affects glucose intolerance in mice. J. Nutr., 136(3):582-7, 2006.

Taouis, M.; Dagou, C.; Ster, C.; Durand, G.; Pinault, M. \& Delarue, J. N-3 polyunsaturated fatty acids prevent the defect of insulin receptor signaling in muscle. Am. J. Physiol. Endocrinol. Metab., 282(3):E664-71, 2002. 
BARBOSA-DA-SILVA, S.; SARMENTO, I. B.; BARGUT, T. C. L.; SOUZA-MELLO, V.; AGUILA, M. B. \& MANDARIM-DE-LACERDA, C. A. Animal models of nutritional induction of type 2 diabetes mellitus. Int. J. Morphol., 32(1):279-293, 2014.

Taylor, P. D. \& Poston, L. Developmental programming of obesity in mammals. Exp. Physiol., 92(2):287-98, 2007.

Teff, K. L.; Elliott, S. S.; Tschop, M.; Kieffer, T. J.; Rader, D.; Heiman, M.; Townsend, R. R.; Keim, N. L.; D'Alessio, D. \& Havel, P. J. Dietary fructose reduces circulating insulin and leptin, attenuates postprandial suppression of ghrelin, and increases triglycerides in women. J. Clin. Endocrinol. Metab., 89(6):2963-72, 2004.

Theys, N.; Bouckenooghe, T.; Ahn, M. T.; Remacle, C. \& Reusens, B. Maternal low-protein diet alters pancreatic islet mitochondrial function in a sex-specific manner in the adult rat. Am. J. Physiol. Regul. Integr. Comp. Physiol., 297(5):R1516-25, 2009.

Tierney, A. C. \& Roche, H. M. The potential role of olive oil-derived MUFA in insulin sensitivity. Mol. Nutr. Food Res.,51(10):123548, 2007.

Villar-Martini, V. C.; Carvalho, J. J.; Neves, M. F.; Aguila, M. B. \& Mandarim-de-Lacerda, C. A. Hypertension and kidney alterations in rat offspring from low protein pregnancies. $J$. Hypertens., 27(6):S47-51, 2009.

Wakutsu, M.; Tsunoda, N.; Shiba, S.; Muraki, E. \& Kasono, K. Peroxisome proliferator-activated receptors (PPARs)independent functions of fish oil on glucose and lipid metabolism in diet-induced obese mice. Lipids Health Dis., 9:101, 2010.

Walker, C. G.; Zariwala, M. G.; Holness, M. J. \& Sugden, M. C. Diet, obesity and diabetes: a current update. Clin. Sci. (Lond.), 112(2):93-111, 2007.

Wild, S.; Roglic, G.; Green, A.; Sicree, R. \& King, H. Global prevalence of diabetes: estimates for the year 2000 and projections for 2030. Diabetes Care, 27(5):1047-53, 2004.

Ye, J. Mechanisms of insulin resistance in obesity. Front. Med., 7(1):14-24, 2013.
Correspondence to: Laboratório de Morfometria, Metabolismo e Doença Cardiovascular Centro Biomédico, Instituto de Biologia Universidade do Estado do Rio de Janeiro Av. 28 de Setembro 87 fds.20551-030

Rio de Janeiro, RJ

BRAZIL

Phone/Fax: +55 21 2868-8033

Email: mandarim@uerj.br

URL: www.Immc.uerj.br

Received: 23-12-2013

Accepted: 12-01-2014 